\title{
Developing Neonatal Rat Sympathetic and Sensory Neurons Differ in Their Regulation of 5- $\mathrm{HT}_{3}$ Receptor Expression
}

\author{
Madelaine Rosenberg, Brigitte Pié, and Ellis Cooper \\ Department of Physiology, McGill University, Montréal, Québec, Canada H3G 1 Y6
}

Serotonin $5-\mathrm{HT}_{3}$ receptors $\left(5-\mathrm{HT}_{3} \mathrm{Rs}\right)$ are ligand-gated ion channels expressed by many peripheral neurons and are involved in several physiological processes. To learn more about the developmental regulation of $5-\mathrm{HT}_{3} \mathrm{R}$ expression, we investigated rat sympathetic and vagal sensory neurons. We found that sympathetic and sensory neurons differ in their regulation of $5-\mathrm{HT}_{3} \mathrm{R}$ expression during early postnatal life and as these neurons develop in culture. In SCG neurons $5-\mathrm{HT}_{3} \mathrm{R}$ transcript levels are low at postnatal day 1 (P1) and increase 7.5-fold by $\mathrm{P} 21$; this increase occurs even after elimination of preganglionic innervation. In comparison, $5-\mathrm{HT}_{3} \mathrm{R}$ mRNA levels in $\mathrm{P} 1$ nodose neurons are over 14-fold greater than in P1 SCG and change little by $\mathrm{P} 21$. We show that $5-\mathrm{HT}_{3} \mathrm{R}$ transcript levels in nodose neurons depend on intact target innervation and drop by $60 \%$ after axotomy. When P1 SCG neurons develop in culture, we observed a significant increase in $5-\mathrm{HT}_{3} \mathrm{R}$ expression: after $7 \mathrm{~d}$ in culture, transcript levels increase ninefold versus a threefold increase for neurons developing for $7 \mathrm{~d}$ in vivo. In contrast, $5-\mathrm{HT}_{3} \mathrm{R}$ mRNA levels in cultured nodose neurons drop by $70 \%$ within $24 \mathrm{hr}$; however, this drop is transient. After $2 \mathrm{~d}$, transcript levels begin to increase, and after $7 \mathrm{~d}$, they are above initial values. We show that this delayed increase in $5-\mathrm{HT}_{3} \mathrm{R}$ expression depends on neurotrophins. In both nodose and sympathetic neurons we found that the changes in $5-\mathrm{HT}_{3} \mathrm{R}$ gene expression correlate directly with the appearance of 5-HTevoked current densities.

Key words: 5- $\mathrm{HT}_{3}$ receptor; ligand-gated ion channel; sympathetic; superior cervical ganglion; sensory; nodose; trigeminal; mRNA expression; neurotrophins; axotomy
The serotonin $5-\mathrm{HT}_{3}$ receptor $\left(5-\mathrm{HT}_{3} \mathrm{R}\right)$, a neurotransmittergated ion channel (Yakel and Jackson, 1988; Derkach et al., 1989; Maricq et al., 1991) present on many mammalian peripheral neurons, participates in several diverse physiological functions (Fozard, 1984; Jackson and Yakel, 1995). Activation of 5-HT 3 Rs located on peripheral vagal sensory nerve endings initiates reflexes affecting respiration, circulation, emesis, and swallowing (Douglas, 1975; Sanders-Bush and Mayer, 1996). 5- $\mathrm{HT}_{3} \mathrm{Rs}$ on spinal and vagal sensory neurons are involved in nociceptive signaling and nausea (Fozard, 1984). In the CNS $5-\mathrm{HT}_{3} \mathrm{Rs}$ are implicated in anxiety, depression, and drug dependence (Apud, 1993; Greenshaw, 1993). In addition, $5-\mathrm{HT}_{3} \mathrm{Rs}$ are expressed by sympathetic neurons; however, the role for these receptors in sympathetic function has not been fully determined (Wallis and North, 1978; Yang et al., 1992).

Many vagal afferent neurons expressing $5-\mathrm{HT}_{3} \mathrm{Rs}$ are located in the nodose ganglion. These sensory neurons have typical unipolar polarities; their axons bifurcate into a peripheral branch that innervates much of the viscera, including heart, lungs, trachea, and gut, and a central branch that terminates mainly in the nucleus tractus solitarius (Andresen and Kunze, 1994). The physiological responses to serotonin elicited from these vagal afferents depend, to a large extent, on the functional densities of $5-\mathrm{HT}_{3} \mathrm{Rs}$

\footnotetext{
Received March 24, 1997; revised June 18, 1997; accepted June 23, 1997.

E.C. is supported by the Medical Research Council of Canada and the Heart and Stroke Foundation. M.R. is supported by a doctoral fellowship from the Heart and Stroke Foundation. We thank T. Inoue for assistance in preparing the figures, Dr. P. Séguéla for providing the partial rat $5-\mathrm{HT}_{3} \mathrm{R} \mathrm{cDNA}$, Dr. S. Carbonetto for providing laminin, and Drs. J. Diamond and P. Barker for critically reviewing this manuscript Correspondence should be addressed to Dr. Ellis Cooper, Department of Physiology, McIntyre Medical Building, Room 1127, 3655 Drummond Street, Montréal, Québec, Canada H3G 1Y6.

Copyright (C) 1997 Society for Neuroscience $0270-6474 / 97 / 176629-10 \$ 05.00 / 0$
}

at these nerve endings. However, the factors and mechanisms that ensure the appropriate expression of $5-\mathrm{HT}_{3} \mathrm{Rs}$ on these nerve terminals are largely unknown.

Recent studies have shown that during embryonic development $5-\mathrm{HT}_{3} \mathrm{R}$ gene expression in nodose ganglia is observed as early as embryonic day 10 (E10) in rodents (Johnson and Heinemann, 1995; Tecott et al., 1995) and that by birth these ganglia contain abundant 5- $\mathrm{HT}_{3} \mathrm{R}$ mRNA (Tecott et al., 1995). In contrast, $5-\mathrm{HT}_{3} \mathrm{R}$ expression in embryonic sympathetic neurons is low, and at birth few sympathetic neurons have detectable levels of 5-HT ${ }_{3}$ R mRNA (Johnson and Heinemann, 1995). These results suggest that embryonic sensory and sympathetic neurons use different mechanisms to regulate $5-\mathrm{HT}_{3} \mathrm{R}$ gene expression. Our interest is to learn more about factors and mechanisms that influence $5-\mathrm{HT}_{3} \mathrm{R}$ expression as peripheral neurons differentiate.

In this study we have asked (1) whether the expression of $5-\mathrm{HT}_{3} \mathrm{Rs}$ in vagal sensory neurons from the nodose ganglion changes during the first few postnatal weeks, a time when many autonomic reflexes become active; (2) whether $5-\mathrm{HT}_{3} \mathrm{R}$ expression depends on intact target innervation; (3) whether neurotrophins influence $5-\mathrm{HT}_{3} \mathrm{R}$ expression by nodose neurons; and (4) whether the regulation of $5-\mathrm{HT}_{3} \mathrm{R}$ expression in neonatal nodose neurons is similar to that which occurs in sympathetic neurons.

Our results demonstrate that $5-\mathrm{HT}_{3} \mathrm{R}$ transcript levels in neonatal nodose neurons are relatively abundant, change little over the first 3 postnatal weeks, and depend on target innervation. In comparison, we find that in SCG neurons $5-\mathrm{HT}_{3} \mathrm{R}$ transcript levels increase steadily and are 7.5-fold greater at P21 than at P1; this increase occurs even after elimination of the preganglionic innervation. Our results with SCG and nodose neurons in culture indicate that the regulation of $5-\mathrm{HT}_{3} \mathrm{R}$ expression by sympathetic 
neurons differs from that by nodose neurons during neonatal development.

An abstract of our initial results has appeared previously (Rosenberg et al., 1994).

\section{MATERIALS AND METHODS}

\section{Tissue samples and RNA extraction}

Superior cervical ganglia (SCG), nodose ganglia, and trigeminal ganglia were dissected from postnatal day 1 (P1), P7, P14, and P21 rats (Sprague Dawley CD strain, Charles River, Canada). Total RNA was prepared from these tissues, using the guanidium isothiocyanate-phenolchloroform extraction method of Chomczynski and Sacchi (1987). The ganglia were placed into ice-cold L-15 media without sodium bicarbonate during the dissection, and then placed into GTC solution $(+\beta-$ mercaptoethanol) and homogenized for $10 \mathrm{sec}$ with a Polytron (Brinkmann Instruments, Rexdale, Ontario, Canada). Total RNA was prepared from this lysate by standard phenol-chloroform extraction and ethanol precipitation.

$S C G$ preganglionic denervation and nodose axotomy. The surgical procedures used to cut the preganglionic nerve to the SCG in P1 rats were similar to those described previously (Voyvodic, 1987; McFarlane and Cooper, 1992). Briefly, P1 rats were anesthetized by cooling on ice, and the right sympathetic trunk was exposed and crushed midway between the ganglion and the first rib. Then the trunk was cut rostral to the crush, and the caudal stump was pushed away ventrally to prevent regeneration. The animals were returned to their mother, and 2 weeks after the surgery the denervated SCG ganglia were dissected and total cellular RNA was prepared from the ganglia as described above. Total cellular RNA also was prepared from the contralateral control SCG ganglia, the preganglionic inputs of which were left intact. Similar surgical procedures were performed for nodose axotomy in $\mathrm{P} 0$ and $\mathrm{P} 8$ rats. A partial right nodose axotomy was performed by crushing and cutting the vagus nerve midway between the nodose ganglion and the first rib; the caudal stump was pushed away to prevent regeneration. After $24 \mathrm{hr}$ the axotomized and control nodose ganglia were dissected, and total RNA was prepared as described above.

\section{Neuronal cultures and RNA extraction}

SCG and nodose ganglia were dissected from P1 animals and dissociated mechanically and enzymatically as previously described (Mandelzys and Cooper, 1992; McFarlane and Cooper, 1992). Briefly, the ganglia were dissected under sterile conditions from animals killed by cervical dislocation. The ganglia were incubated for $15 \mathrm{~min}$ at $37^{\circ} \mathrm{C}$ in HBSS (without $\mathrm{Ca}^{2+}$ or $\left.\mathrm{Mg}^{2+}\right)$ containing collagenase $(1 \mathrm{mg} / \mathrm{ml}$, type I, Sigma, St. Louis, MO) and dispase $(2.4 \mathrm{mg} / \mathrm{ml}$, grade II, Boehringer-Mannheim, Indianapolis, IN). Then the ganglia were transferred to a similar solution containing only dispase, and the ganglia were triturated gently every 15 min with a fire-polished Pasteur pipette for a total of 3-4 hr. After dissociation the cells were centrifuged through a $35 \%$ Percoll density gradient (Pharmacia, Dorval, Québec, Canada) to separate neurons from non-neuronal cells. The neuronal fraction was washed twice with L-15 medium supplemented with $10 \%$ horse serum and plated at a density of $5000-8000$ cells $/ \mathrm{cm}^{2}$ onto laminin-coated $\left(30 \mu \mathrm{g} / \mathrm{ml}\right.$, overnight at $4{ }^{\circ} \mathrm{C}$; gift of Dr. S. Carbonetto, McGill University, Canada) Aclar coverslips (Allied Chemicals, Clifton, NJ) in modified Petri dishes. The Petri dishes (35 mm, Corning, Corning, NY) were modified by boring a $1.5 \mathrm{~cm}$ diameter hole in the bottom and then gluing Aclar coverslips from underneath with silicone rubber (3140 MIL-A-46146 RVT coating, Dow Corning, Midland, MI); this created a $2-\mathrm{mm}$-deep well with a volume of $\sim 200 \mu \mathrm{l}$. The neurons were grown in $1.5 \mathrm{ml}$ of L-15 medium supplemented with 5\% rat serum, vitamins, cofactors, penicillin, streptomycin, and sodium bicarbonate as previously described (Hawrot and Patterson, 1979). For SCG neurons the media was supplemented with nerve growth factor (2.5S NGF, $25 \mathrm{ng} / \mathrm{ml}$ ). Nodose neurons were grown in the L-15 growth media described above either without added neurotrophins; with NGF, brain-derived neurotrophic factor (BDNF, $25 \mathrm{ng} / \mathrm{ml}$; gift of Amgen, Thousand Oaks, CA), and neurotrophin-3 (NT-3, $25 \mathrm{ng} / \mathrm{ml}$; gift of Amgen); or with NGF, BDNF, NT-3, and elevated potassium (final $\left[\mathrm{K}^{+}\right]$ $=40 \mathrm{mM}$ ). After $2 \mathrm{~d}$ in culture, cytosine arabinof uranoside (Ara-C, 10 $\mu \mathrm{M}$; Sigma) was added to the cultures for $2-3 \mathrm{~d}$ to kill the few remaining non-neuronal cells. The cultures were maintained at $37^{\circ} \mathrm{C}$ in a humidified incubator with an atmosphere of $5 \% \mathrm{CO}_{2} / 95 \%$ air. The media were replaced every $3 \mathrm{~d}$ with fresh media. In some experiments we treated nodose neurons with $1 \mu \mathrm{g} / \mathrm{ml}$ cycloheximide (1 in 5000 dilution of a 5 $\mathrm{mg} / \mathrm{ml}$ ethanol solution; Sigma) for the first 10 or $24 \mathrm{hr}$ after dissection; this concentration of cycloheximide previously has been shown to block protein synthesis in cultured neonatal SCG neurons (Martin et al., 1988). Cycloheximide was added to the plating media and all solutions used during the dissociation procedure. Sister cultures were treated with vehicle alone and showed no difference from untreated controls.

Total cellular RNA was prepared from cultures of P1 SCG and nodose neurons at day 0 (D0; immediately after dissociation), D1, D2, D4, D7, or D14 either with the RNeasy total RNA kit (Qiagen, Hilden, Germany) or with the guanidium isothiocyanate-phenol-chloroform extraction method as previously described (De Koninck and Cooper, 1995). Typically, four Petri dishes were pooled for each RNA sample. The yield of total RNA obtained with either RNA preparation method was similar and ranged from 2 to $3 \mu \mathrm{g}$. Total RNA also was prepared from the non-neuronal cells in a similar way. Less than $10 \%$ of total cellular RNA from the ganglia was present in non-neuronal cell fractions; previously, we determined that this value changes little over the first 2 weeks of development for SCG (Mandelzys et al., 1994).

\section{RNase protection assays}

RNase protection assays were performed as described by Krieg and Melton (1987) with minor modifications (Mandelzys et al., 1994). Briefly, ${ }^{32} \mathrm{P}$-UTP-labeled antisense RNA probes to rat $5-\mathrm{HT}_{3} \mathrm{R}$ and glyceraldehyde-3-phosphate dehydrogenase (GAPDH) were transcribed in vitro with T7 RNA polymerase from linearized plasmids containing portions of the cDNA clones. The $5-\mathrm{HT}_{3} \mathrm{R}$ antisense probe was synthesized from a partial rat $5-\mathrm{HT}_{3} \mathrm{R}$ cDNA clone (in pBluescript SK, Stratagene, La Jolla, CA; gift of Dr. P. Séguéla, Montreal Neurological Institute, Canada) obtained by RT-PCR amplification, using oligonucleotide primers for the mouse $5-\mathrm{HT}_{3} \mathrm{R}$ cDNA sequence (Maricq et al., 1991). This partial rat 5-HT $\mathrm{H}_{3} \mathrm{R}$ cDNA was sequenced and found to be identical to the published rat 5- $\mathrm{HT}_{3} \mathrm{R}$ cDNA sequence (Miyake et al., 1995). The $5-\mathrm{HT}_{3} \mathrm{R}$ antisense probe protects 563 bases of the rat $5 \mathrm{HT}_{3} \mathrm{R}$ transcript between positions 268 and 831 of the rat cDNA sequence (Miyake et al., 1995). Both nodose and SCG neurons express two alternatively spliced $5-\mathrm{HT}_{3} \mathrm{R}$ transcripts that encode receptor proteins that differ by five amino acids located between hydrophobic domains M3 and M4 at position 1153 (Miquel et al., 1995; Miyake et al., 1995); however, differences in the physiological role of the variants remain unclear (Downie et al., 1994). The probe we used detects both splice isoforms. The GAPDH antisense probe, synthesized from the mouse GAPDH (mouse pTRI-GAPDH, Ambion, Austin, TX), protects 316 bases of the rat GAPDH mRNA transcript. The thermal stabilities of the probes, based on their melting temperatures, were found to differ by $<1^{\circ} \mathrm{C}$.

The labeled riboprobes were gel-purified before use. For each reaction $1 \mu \mathrm{g}$ of total RNA was combined with radiolabeled $5-\mathrm{HT}_{3} \mathrm{R}$ probe $(200,000 \mathrm{cpm})$ and GAPDH probe $(30,000 \mathrm{cpm})$ and allowed to hybridize at $60^{\circ} \mathrm{C}$ overnight. The unhybridized single-stranded RNAs were digested with RNase T1 (Sigma), and the protected RNA/RNA hybrids were denatured and separated on $5 \%$ polyacrylamide $8 \mathrm{M}$ urea gels. The gels were dried, exposed to a phosphorimaging screen (Fujix BAS 2000 and Molecular Dynamics, Sunnyvale, CA) to quantify the hybridization signals, and then exposed to X-ray film (Kodak XAR, Rochester, NY) with intensifying screens for $2-3 \mathrm{~d}$ at $-80^{\circ} \mathrm{C}$. The $5-\mathrm{HT}_{3} \mathrm{R}$ hybridization signals were normalized to those for GAPDH to take into account minor differences in the amount of RNA used per reaction. Each RNA sample was tested in duplicate or triplicate reactions. The relative amount of $5-\mathrm{HT}_{3} \mathrm{R}$ mRNA expression for each condition was the average of the values determined from three or more independently prepared RNA samples. The mRNA levels for both $5-\mathrm{HT}_{3} \mathrm{R}$ and GAPDH in P1 SCG and $\mathrm{P} 1$ nodose ganglia were similar to those of freshly dissociated D0 SCG and D0 nodose neurons, respectively, because the contribution of non-neuronal cells to the total ganglionic RNA was small (Mandelzys et al., 1994).

\section{In situ hybridization}

The in situ hybridization experiments were performed on tissue sections and on neuronal cell cultures according to the methods of Barthel and Raymond (1993) and Litman et al. (1993). Briefly, antisense digoxigenin (DIG)-labeled $5-\mathrm{HT}_{3} \mathrm{R}$ probe was synthesized by in vitro transcription with T7 RNA polymerase and DIG-11-UTP (Boehringer Mannheim) and the plasmid containing the portion of the rat $5-\mathrm{HT}_{3} \mathrm{R}$ cDNA described above. Because we were unable to quantify accurately the concentration of DIG-labeled probes with spectrophotometry, we measured 
the amount of DIG-labeled antisense $5-\mathrm{HT}_{3} \mathrm{R}$ probe by RNase protection assays with ${ }^{32} \mathrm{P}$-labeled sense $5-\mathrm{HT}_{3} \mathrm{R}$ probe; this also allowed us to verify that the in vitro transcription produced full-length DIG-labeled probes. To do this, we first synthesized unlabeled antisense $5-\mathrm{HT}_{3} \mathrm{R}$ cRNA, which we quantified by spectrophotometry, and then hybridized different amounts of unlabeled antisense $5-\mathrm{HT}_{3} \mathrm{R}$ cRNA with 200,000 $\mathrm{cpm}$ of ${ }^{32} \mathrm{P}$-labeled sense $5-\mathrm{HT}_{3} \mathrm{R}$ to generate a standard curve. We then compared the hybridization signals obtained with the DIG-labeled antisense $5-\mathrm{HT}_{3} \mathrm{R}$ probe to the standard curve to determine the concentration of DIG-labeled antisense $5-\mathrm{HT}_{3} \mathrm{R}$ probe.

The in situ RNA hybridization experiments were performed on freshfrozen cryostat sections of P5 and P21 SCG and nodose ganglia. The SCG and nodose ganglia were dissected together with the carotid artery, embedded in O.C.T. Compound (Tissue Tek, Miles, Elkhart, IN) and frozen in isopentane cooled on dry ice. The frozen tissue samples were cut at $16 \mu \mathrm{m}$ thickness with a $-20^{\circ} \mathrm{C}$ cryostat and placed onto Probe On Plus slides (Fisher Scientific, Pittsburgh, PA). Next, the sections were fixed for 5 min with $3 \%$ paraformaldehyde in $0.1 \mathrm{M}$ Na phosphate buffer $\left(0.1 \mathrm{M} \mathrm{NaH}_{2} \mathrm{PO}_{4} / 0.1 \mathrm{M} \mathrm{Na}_{2} \mathrm{HPO}_{4}, \mathrm{pH} 7.4\right)$, rinsed with PBS, rinsed with DEPC water, dehydrated with alcohol, air-dried, and stored at $-80^{\circ} \mathrm{C}$. The sections were warmed to room temperature and prehybridized for 3 $\mathrm{hr}$ at $43^{\circ} \mathrm{C}$ in a solution containing salmon sperm DNA $(250 \mu \mathrm{g} / \mathrm{ml}$, Pharmacia), yeast tRNA $(500 \mu \mathrm{g} / \mathrm{ml}$, Sigma), ribonucleoside vanadyl complex (20 mm, New England Biolabs, Beverly, MA), 4× SSC (0.3 M $\mathrm{NaCl}, 0.03 \mathrm{M}$ Na citrate in DEPC water), $50 \%$ formamide, $3 \times$ Denhart's solution, $1 \%$ sarcosyl, and $20 \mathrm{~mm}$ Na phosphate buffer, $\mathrm{pH}$ 6.8. Then the prehybridization solution was replaced with the hybridization solution that contained the same ingredients plus dextran sulfate (10\%), DTT (60 $\mathrm{mM})$, and differing amounts of riboprobe $(0.25-12.5 \mathrm{ng} / \mu \mathrm{l})$. The sections were incubated at $43^{\circ} \mathrm{C}$ overnight, washed $3 \times$ for $15 \mathrm{~min}$ in $2 \times \mathrm{SSC}$ at $43^{\circ} \mathrm{C}$, and treated with RNase T1 $(1000 \mathrm{U} / \mathrm{ml})$ and RNase A $(2 \mu \mathrm{g} / \mathrm{ml}$; Pharmacia) in RNase buffer $(0.3 \mathrm{M} \mathrm{NaCl}, 0.1 \mathrm{~m}$ Tris, $\mathrm{pH} 7.5$, and $5 \mathrm{~mm}$ NaEDTA, pH 8.0) for $30 \mathrm{~min}$ at $37^{\circ} \mathrm{C}$ to digest unhybridized RNAs. The sections were rinsed with $1 \times \mathrm{SSC}, 0.5 \times \mathrm{SSC}$, and $0.1 \times \mathrm{SSC}$ for $15 \mathrm{~min}$ each at $43^{\circ} \mathrm{C}$. The sections were rinsed with TBS, incubated for $1 \mathrm{hr}$ at room temperature in TBS containing $1 \%$ blocking reagent for nucleic acids (Boehringer Mannheim), and then incubated for $1 \mathrm{hr}$ with same buffer supplemented with $3.4 \mu \mathrm{l} / \mathrm{ml}$ of anti-DIG-alkaline phosphatase conjugate, Fab fragment (Boehringer Mannheim). The sections were rinsed $3 \times$ with TBS for $10 \mathrm{~min}$ each, and the bound probe was detected by standard alkaline phosphatase histochemistry. The reactions typically were developed for $18-24 \mathrm{hr}$ in the dark. We performed controls with RNase $\mathrm{T} 1$ pretreatment or with DIG-labeled sense $5-\mathrm{HT}_{3} \mathrm{R}$ probe on tissue sections; these controls indicated that nonspecific signals were low. To verify the specificity of the $5-\mathrm{HT}_{3} \mathrm{R}$ probe, we pretreated the tissue sections with 400 -fold excess unlabeled antisense $5-\mathrm{HT}_{3} \mathrm{R}$ probe, which competitively blocked the hybridization of the DIG-labeled antisense $5-\mathrm{HT}_{3} \mathrm{R}$ probe. Adjacent sections were stained with Masson's trichrome stain (Sigma) to identify the cellular components of the two ganglia.

In situ hybridizations also were performed on P1 SCG and nodose neurons grown in culture for $7 \mathrm{~d}$. The nodose neurons were grown in the presence of NGF, BDNF, and NT-3 as described above. The cell cultures were fixed for $10 \mathrm{~min}$ with $4 \%$ paraformaldehyde in $0.1 \mathrm{M}$ Na phosphate buffer, $\mathrm{pH} 7.4$, rinsed with PBS, and stored in $70 \%$ ethanol at $-20^{\circ} \mathrm{C}$. The cultured neurons were permeabilized with ice-cold $100 \%$ ethanol, rehydrated with PBS, and then prehybridized and hybridized as described above. We performed similar controls as described above with 400 -fold excess unlabeled $5-\mathrm{HT}_{3} \mathrm{R}$ antisense probe, with RNase $\mathrm{T} 1$ pretreatment, or with DIG-labeled sense $5-\mathrm{HT}_{3} \mathrm{R}$ probe.

\section{Electrophysiology recordings and data analysis}

5-HT-evoked current densities were measured with whole-cell patchclamp techniques (Hamil et al., 1981). The currents were recorded at room temperature $\left(22-24^{\circ} \mathrm{C}\right)$ with a List EPC-7 amplifier, filtered at 1.5 $\mathrm{kHz}$ with an eight-pole Bessel filter (Frequency Devices, Haverhill, MA), and then sampled at $5 \mathrm{kHz}$, displayed, and stored on-line with a 386based PC computer (AT class running at $33 \mathrm{MHz}$ and a $64 \mathrm{~K}$ cache and A/D card; Omega, Stamford, CT). The program PATCHKIT (Alembic Software, Montréal, Canada) was used for data acquisition and analysis. Pipette resistances ranged from 2 to $6 \mathrm{M} \Omega$ and were balanced to zero with the pipette immersed in the perfusion solution. Neurons were voltage-clamped at $-60 \mathrm{mV}$, and 5-HT $(100 \mu \mathrm{M}$ or $1 \mathrm{mM})$ was applied with a rapid agonist application method as previously described (Mandelzys et al., 1995). Tetrodotoxin (TTX) was added to all solutions to eliminate unclamped $\mathrm{Na}^{+}$currents. In some nodose neurons 5-HT application evoked a burst of TTX-insensitive $\mathrm{Na}^{+}$currents that were superimposed on 5-HT-evoked currents; however, because of the rapid time course of the $\mathrm{Na}^{+}$currents, they did not interfere with our ability to measure the amplitude of the 5-HT-evoked currents. The 5-HTevoked current densities were calculated by dividing the peak current by the whole-cell capacitance; the whole-cell capacitance was obtained by integrating the capacity current evoked by a $5 \mathrm{mV}$ hyperpolarizing pulse from a holding potential of $-60 \mathrm{mV}$. The control perfusion solution consisted of (in mM) $140 \mathrm{NaCl}, 5.4 \mathrm{KCl}, 0.33 \mathrm{NaH}_{2} \mathrm{PO} 4,0.44 \mathrm{KH}_{2} \mathrm{PO}_{4}$, $0.28 \mathrm{CaCl}_{2}, 0.18 \mathrm{MgCl}_{2}, 10 \mathrm{HEPES}, 5.6$ glucose, and 2 glutamine with $5 \mu \mathrm{g} / \mathrm{ml}$ phenol red and $0.5 \mu \mathrm{M}$ TTX (Sigma); $\mathrm{pH}$ was adjusted to 7.4. For drug application we used an identical solution in which we added 5-HT (0.1-1 mM). The pipette solution contained (in $\mathrm{mM}) 65 \mathrm{KF}, 55 \mathrm{KAc}, 5$ $\mathrm{NaCl}, 0.2 \mathrm{CaCl}_{2}, 1 \mathrm{MgCl}_{2}, 10$ EGTA, and $10 \mathrm{HEPES} ; \mathrm{pH}$ was adjusted to 7.4. During the recording the cultures were perfused at $1 \mathrm{ml} / \mathrm{min}$ with control perfusion solution.

Statistical analysis. The results are expressed as the mean \pm SEM, and Student's $t$ tests were used to assess statistical significance.

\section{RESULTS}

We present our results on $5-\mathrm{HT}_{3} \mathrm{R}$ gene expression in neonatal SCG and nodose neurons in two parts: (1) during early postnatal development in vivo and (2) as these neurons develop in culture.

\section{$5-\mathrm{HT}_{3} \mathrm{R}$ gene expression in neonatal SCG and nodose} neurons in vivo

\section{5-HT $T_{3} R \mathrm{mRA}$ levels increase in SCG during early postnatal development}

We examined 5- $\mathrm{HT}_{3} \mathrm{R}$ gene expression in rat SCG during the first 3 weeks of postnatal development, using RNase protection assays (Fig. $1 A$ ). For each reaction we assayed GAPDH mRNA levels as internal controls and quantified the hybridization signals with a phosphorimaging system. Figure $1 B$ shows the changes in $5-\mathrm{HT}_{3} \mathrm{R}$ mRNA levels relative to those at P1. These results demonstrate that $5-\mathrm{HT}_{3} \mathrm{R}$ gene expression increases steadily over the first 3 postnatal weeks such that by P21 the levels are 7.5-fold greater than at $\mathrm{P} 1$.

To verify that $5-\mathrm{HT}_{3} \mathrm{R}$ transcripts are present only in neurons of the SCG, we dissociated P1 SCG, separated neurons from non-neuronal cells by using a density gradient, and measured $5-\mathrm{HT}_{3} \mathrm{R}$ mRNA levels in both cell fractions. Our results indicate that these transcripts are detectable only in the neuronal fractions (data not shown).

Influence of preganglionic innervation. During the first 3 postnatal weeks preganglionic nerve terminals form $90 \%$ of their adult number of synapses on SCG neurons (Smolen and Raisman, 1980). To determine whether the increase in $5-\mathrm{HT}_{3} \mathrm{R}$ gene expression in SCG neurons during postnatal development is a consequence of increasing innervation, we cut the preganglionic nerve at $\mathrm{P} 1$ and measured $5-\mathrm{HT}_{3} \mathrm{R}$ mRNA levels in the denervated neurons 2 weeks later. We found that the $5-\mathrm{HT}_{3} \mathrm{R}$ mRNA levels in denervated neurons were not significantly different $(p>$ 0.2 ) from innervated contralateral or unoperated P14 SCG neurons (Fig. $1 C$ ). These results indicate that the developmental increase in $5-\mathrm{HT}_{3} \mathrm{R}$ gene expression in SCG neurons during the postnatal period does not require preganglionic innervation.

\section{$5-H T_{3} R$ transcripts are differentially expressed in SCG and nodose ganglia}

To determine what proportion of neurons in the ganglia express $5-\mathrm{HT}_{3} \mathrm{R}$ transcripts, we performed in situ hybridization experiments, using DIG-labeled riboprobes. Because one of the objectives of our study was to compare $5-\mathrm{HT}_{3} \mathrm{R}$ expression in sympathetic neurons with that in sensory neurons, we used tissue sections that included both the SCG and nodose ganglion (Fig. 2). Our results from P5 and P21 ganglia indicate that most SCG 
A

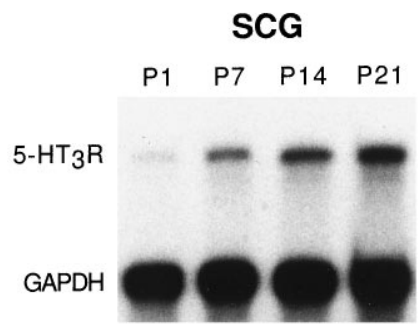

B
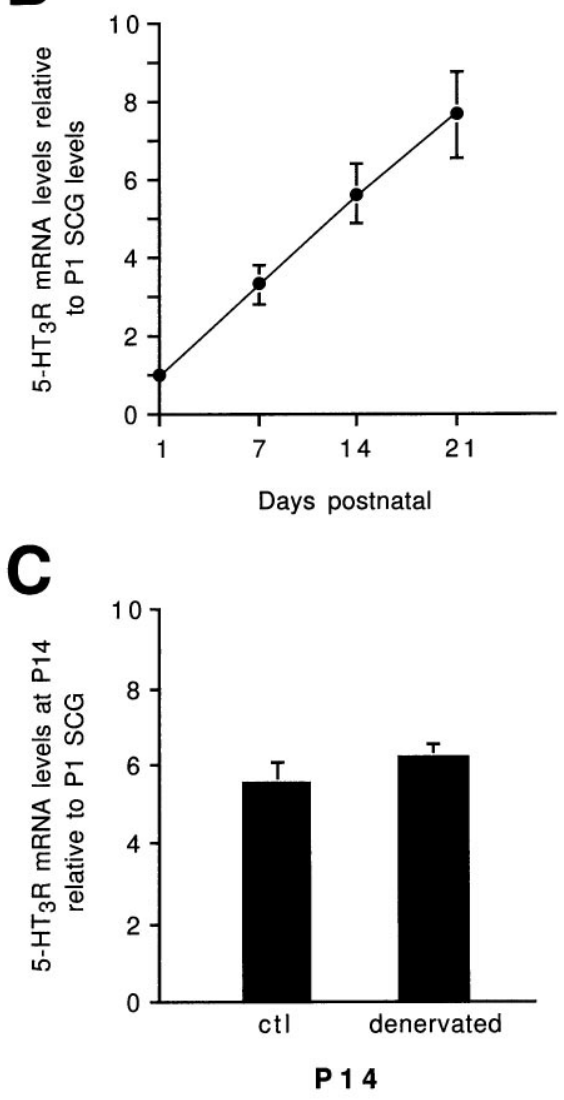

Figure 1. Developmental increase in $5-\mathrm{HT}_{3} \mathrm{R}$ mRNA expression in SCG. $A$, RNase protection assay for $5-\mathrm{HT}_{3} \mathrm{R}$ and GAPDH mRNA expression in total RNA isolated from $P 1, P 7, P 14$, and $P 21$ rat SCG. Total RNA (1 $\mu \mathrm{g})$ was used for each reaction; the protected riboprobe sizes are 563 bases for $5-\mathrm{HT}_{3} \mathrm{R}$ and 316 bases for GAPDH. GAPDH mRNA expression was assessed to ensure that equal amounts of total RNA were used in each reaction. $B$, Quantification of $5-\mathrm{HT}_{3} \mathrm{R}$ mRNA expression in SCG $5-\mathrm{HT}_{3} \mathrm{R}$ expression increases 7.5 -fold during the first 3 weeks of postnatal life. $C$, This figure shows that when P1 SCG ganglia are denervated for 2 weeks, there is no significant change in $5-\mathrm{HT}_{3} \mathrm{R}$ mRNA expression, suggesting that innervation does not contribute to the observed developmental increase in $5-\mathrm{HT}_{3} \mathrm{R}$ expression. The values represent the mean of six to eight experiments, and the error bars represent the SEM.

neurons express $5-\mathrm{HT}_{3} \mathrm{R}$ mRNA and that the levels in these neurons increase with development, as we show quantitatively with RNase protection assays (see Fig. 1). Figure 2 also shows that nodose neurons contain abundant $5-\mathrm{HT}_{3} \mathrm{R}$ transcripts, consistent with previous studies reporting $5-\mathrm{HT}_{3} \mathrm{R}$ mRNA expression in embryonic nodose neurons (Johnson and Heinemann, 1995; Tecott et al., 1995). The medial neurons in nodose ganglia appear to have lower amounts of $5-\mathrm{HT}_{3} \mathrm{R}$ mRNA than the lateral neu-

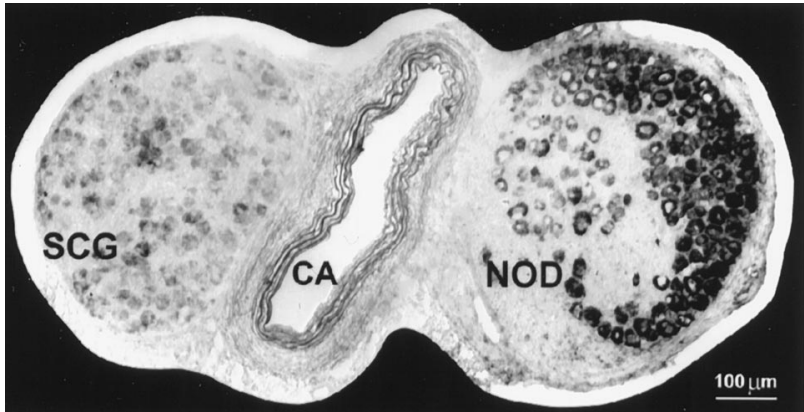

Figure 2. Differential $5-\mathrm{HT}_{3} \mathrm{R}$ mRNA expression in SCG and nodose neurons. In situ hybridization with DIG-labeled antisense $5-\mathrm{HT}_{3} \mathrm{R}$ probe on a section through $\mathrm{P} 21$ rat superior cervical ganglia $(S C G)$, carotid artery $(C A)$, nodose $(N O D)$, and associated connective tissue. This figure is a montage of photomicrographs taken with a $20 \times$ objective and DIC optics on a Zeiss Axiovert 35 microscope. This figure shows that $5-\mathrm{HT}_{3} \mathrm{R}$ mRNA is expressed at high levels in most nodose neurons and at lower levels in most SCG neurons and is not detectable in non-neuronal cells.

rons. This pattern may result from different target innervation. In cat and rabbit, nodose neurons that project to specific targets are organized topographically within the ganglion (Mei, 1970; Portalier and Vigier, 1979; Donoghue et al., 1982). However, comparable experiments have not been done in rat. Our results with in situ hybridizations also confirm that $5-\mathrm{HT}_{3} \mathrm{R}$ transcripts are present only in the neurons and not in the non-neuronal cells of either ganglia.

\section{$5-H T_{3} R$ mRNA levels in nodose neurons change little during early postnatal development}

We quantified 5- $\mathrm{HT}_{3} \mathrm{R}$ mRNA levels in nodose neurons during postnatal development, using RNase protection assays (Fig. $3 A, B)$. In contrast to the developmental increase observed in $\mathrm{SCG}, 5-\mathrm{HT}_{3} \mathrm{R}$ mRNA levels in nodose neurons changed little over the first 3 postnatal weeks. To compare the expression between nodose and SCG, we normalized 5- $\mathrm{HT}_{3} \mathrm{R}$ mRNA hybridization signals to those of GAPDH. At P1 we find that $5-\mathrm{HT}_{3} \mathrm{R}$ mRNA levels in nodose are over 14-fold greater than in SCG (Fig. 3C,D); however, at P21 the 5- $\mathrm{HT}_{3} \mathrm{R}$ mRNA levels in nodose are only threefold higher (Fig. $3 D$ ) because, as we have shown above, the levels in SCG increase significantly during the first few weeks.

Our results indicate that regulation of $5-\mathrm{HT}_{3} \mathrm{R}$ gene expression in nodose neurons differs from that in SCG neurons. To determine whether other sensory neurons regulate $5-\mathrm{HT}_{3} \mathrm{R}$ expression in a similar manner to nodose neurons, we measured $5-\mathrm{HT}_{3} \mathrm{R}$ mRNA levels in trigeminal ganglia. Our results indicate that, unlike nodose neurons, 5- $\mathrm{HT}_{3} \mathrm{R}$ mRNA levels in trigeminal ganglia are low in P1 animals, increase steadily over the first 3 postnatal weeks (data not shown), and are four-to fivefold greater at P21 (Fig. 3D). These results suggest that 5- $\mathrm{HT}_{3} \mathrm{R}$ gene expression is not identical in all sensory neurons.

Effects of axotomy. One factor known to regulate gene expression in peripheral sensory neurons is target innervation (Herdegen and Zimmerman, 1994; Hökfelt et al., 1994a,b). To determine whether target innervation influences $5-\mathrm{HT}_{3} \mathrm{R}$ transcripts levels in nodose neurons, we cut the vagus nerve distal to the ganglion and then quantified $5-\mathrm{HT}_{3} \mathrm{R}$ mRNA levels in the axotomized neurons $24 \mathrm{hr}$ later (Fig. 4). Cutting the vagus nerve in $\mathrm{P} 0$ animals resulted in a $60 \%$ decrease in $5-\mathrm{HT}_{3} \mathrm{R}$ mRNA levels 
A

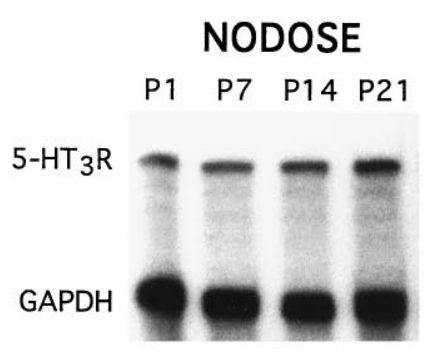

B

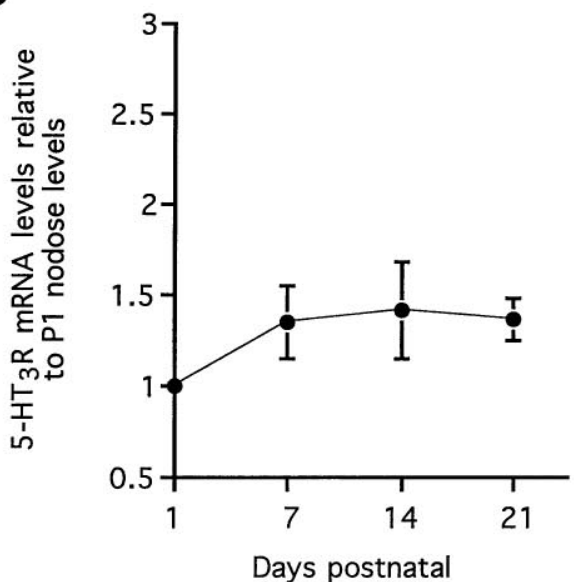

C

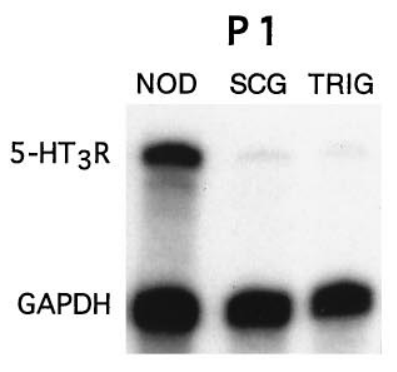

P2 1

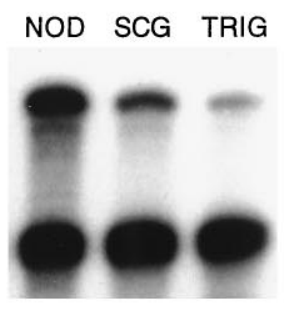

D

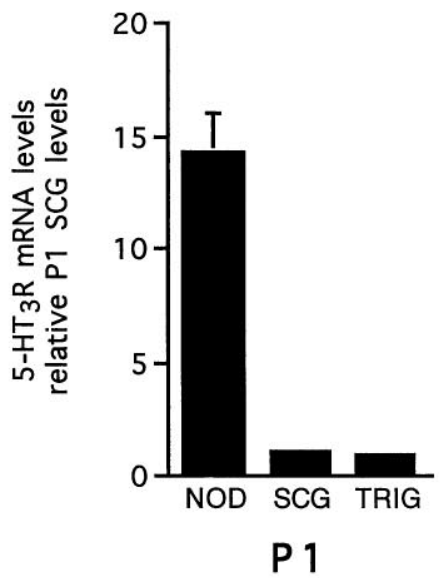

Figure 3. $5-\mathrm{HT}_{3} \mathrm{R}$ mRNA is highly expressed during early postnatal development in nodose ganglia. $A$, RNase protection assay for 5 -HT ${ }_{3} \mathrm{R}$ mRNA expression performed as in Figure 1 on $1 \mu \mathrm{g}$ of total RNA isolated from $P 1, P 7, P 14$, and $P 21$ rat nodose ganglia. $B$, Quantification of 5-HT ${ }_{3} \mathrm{R}$ mRNA expression in nodose: $5-\mathrm{HT}_{3} \mathrm{R}$ expression changes little during the first 3 weeks of postnatal development. $C$, RNase protection assay depicting a comparison of 5- $\mathrm{HT}_{3} \mathrm{R}$ mRNA expression in $1 \mu \mathrm{g}$ of total RNA prepared from $P 1$ and $P 21$ nodose, SCG, and trigeminal ganglia. $D$, Quantification of 5- $\mathrm{HT}_{3} \mathrm{R}$ mRNA expression in nodose (NOD), $S C G$, and trigeminal ganglia (TRIG) at $P 1$ and $P 21$. The values represent the mean of six to eight experiments, and the error bars represent the SEM. In P1 SCG, P1 NOD, and P21 TRIG, the error bars are too small to resolve. This figure shows that at $P 15-\mathrm{HT}_{3} \mathrm{R}$ expression is 14-fold higher in nodose than in SCG or trigeminal. However, in SCG and trigeminal, 5-HT $\mathrm{R}_{3} \mathrm{mRNA}$ expression increases significantly during the first 3 postnatal weeks such that by $P 21$ the levels in nodose are only threefold larger than in SCG and fourfold larger than in trigeminal.

relative to contralateral control neurons. This experiment was done also on P8 animals, and as we found a similar decrease after axotomy, we combined the results from both groups in Figure $4 B$. These findings indicate that $5-\mathrm{HT}_{3} \mathrm{R}$ mRNA expression in postnatal nodose neurons depends on intact target innervation.

\section{$5-\mathrm{HT}_{3} \mathrm{R}$ gene expression in neonatal SCG and nodose neurons in culture}

Most nodose and SCG neurons developing in culture express 5- $\mathrm{HT}_{3} \mathrm{R} \mathrm{mRNA}$

To learn more about the regulation of $5-\mathrm{HT}_{3} \mathrm{R}$ gene expression in peripheral neurons, we investigated sympathetic and nodose neurons developing in culture. Figure 5 shows examples of in situ hybridization experiments with DIG-labeled $5-\mathrm{HT}_{3} \mathrm{R}$ probes on P1 nodose and SCG neurons that had developed in culture for 1 week in the virtual absence of ganglionic non-neuronal cells. Figure 5 shows that most SCG and nodose neurons in these cultures express $5-\mathrm{HT}_{3} \mathrm{R}$ transcripts. To demonstrate that the hybridization signals represent specific $5-\mathrm{HT}_{3} \mathrm{R}$ transcripts, we preincubated nodose cultures with 400 -fold excess unlabeled antisense $5-\mathrm{HT}_{3} \mathrm{R}$ cRNA, which competitively blocked hybridization of the DIG-labeled antisense 5- $\mathrm{HT}_{3} \mathrm{R}$ riboprobe (Fig. $5 C$ ). In addition, pretreatment of the cultures with RNases prevented antisense riboprobe hybridization; similarly, DIG-labeled sense riboprobes did not hybridize (data not shown).

\section{$5-H T_{3} R$ gene expression increases in neonatal SCG neurons developing in culture}

Figure 6 shows that $5-\mathrm{HT}_{3} \mathrm{R}$ mRNA levels increase in P1 SCG neurons developing in culture. The specific increase in $5-\mathrm{HT}_{3} \mathrm{R}$ mRNA levels in cultured neurons is greater than that in vivo: after $7 \mathrm{~d}$ in culture, transcript levels have increased ninefold, whereas after a similar time in vivo there is only a threefold increase (see Fig. $1 B)$. This difference may reflect either that a factor(s) in these cultures stimulates $5-\mathrm{HT}_{3} \mathrm{R}$ gene expression or that an extrinsic factor(s) in vivo modulates its expression.

\section{5- $\mathrm{HT}_{3} \mathrm{R}$ gene expression decreases rapidly and transiently in cultured nodose neurons}

Because neonatal rat nodose neurons express mRNA for trkA, trkB, trkC, and p75 receptors (M. R. and E. C., unpublished observations), we grew $\mathrm{P} 1$ nodose neurons in culture under conditions similar to those of SCG neurons, except that we supplemented the growth media with BDNF and NT-3 in addition to $\mathrm{NGF}$ (all at $25 \mathrm{ng} / \mathrm{ml}$ ). Within $24 \mathrm{hr}$ after plating, $5-\mathrm{HT}_{3} \mathrm{R}$ mRNA levels in cultured nodose neurons drop to $30 \%$ of initial values 
A

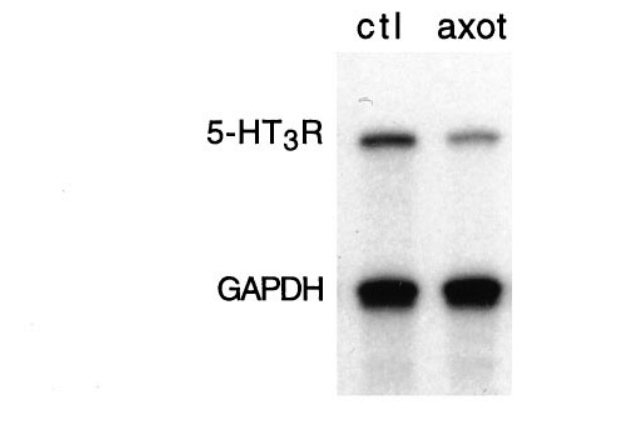

B

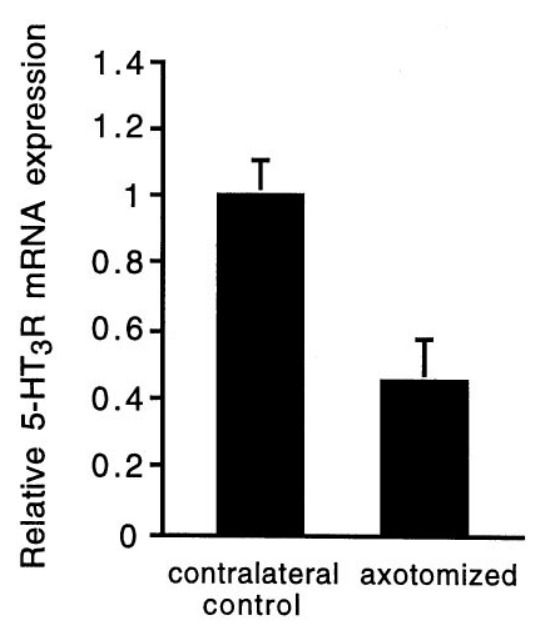

NODOSE

Figure 4. $5-\mathrm{HT}_{3} \mathrm{R}$ gene expression in nodose neurons depends on intact target innervation. $A$, RNase protection assay performed as in Figure 1 on $1 \mu \mathrm{g}$ of total RNA prepared from P1 nodose ganglia that were axotomized $24 \mathrm{hr}$ earlier (axot) and from control contralateral P1 nodose ganglia $(\mathrm{ctl})$. $B$, Mean \pm SEM 5-HT $\mathrm{H}_{3} \mathrm{R}$ RNA levels for axotomized P1 and P9 nodose ganglia are significantly different from control contralateral ganglia $(p<$ $0.001 ; n=12)$.

(Fig. 7A). In early experiments we supplemented the media with only NGF or BDNF and observed similar decreases (data not shown). This rapid decrease in $5-\mathrm{HT}_{3} \mathrm{R}$ mRNA levels is similar to that observed in axotomized neurons in vivo and presumably occurs because the axons of these neurons are cut when the neurons are placed in culture.

Lack of effect of elevated $\mathrm{K}^{+}$on the initial decrease. In a previous study we observed a significant decrease in mRNA levels for the $\alpha_{7}$ neuronal nicotinic acetylcholine receptor (nAChR) subunit in cultured SCG neurons (De Koninck and Cooper, 1995), similar to the decrease we observed in $5-\mathrm{HT}_{3} \mathrm{R}$ mRNA levels in cultured nodose neurons. We showed that the decrease in $\alpha_{7}$ mRNA in SCG neurons could be prevented by culturing the neurons in elevated $(40 \mathrm{~mm}) \mathrm{K}^{+}$; the resultant depolarization increased intracellular $\mathrm{Ca}^{2+}$ levels and increased $\alpha_{7}$ mRNA levels by activating a $\mathrm{Ca}^{2+} /$ calmodulin-dependent kinase (CaM kinase) pathway (De Koninck and Cooper, 1995). To test whether similar mechanisms regulate $5-\mathrm{HT}_{3} \mathrm{R}$ gene expression, we cultured nodose neurons in elevated $\mathrm{K}^{+}$; however, this did not prevent the

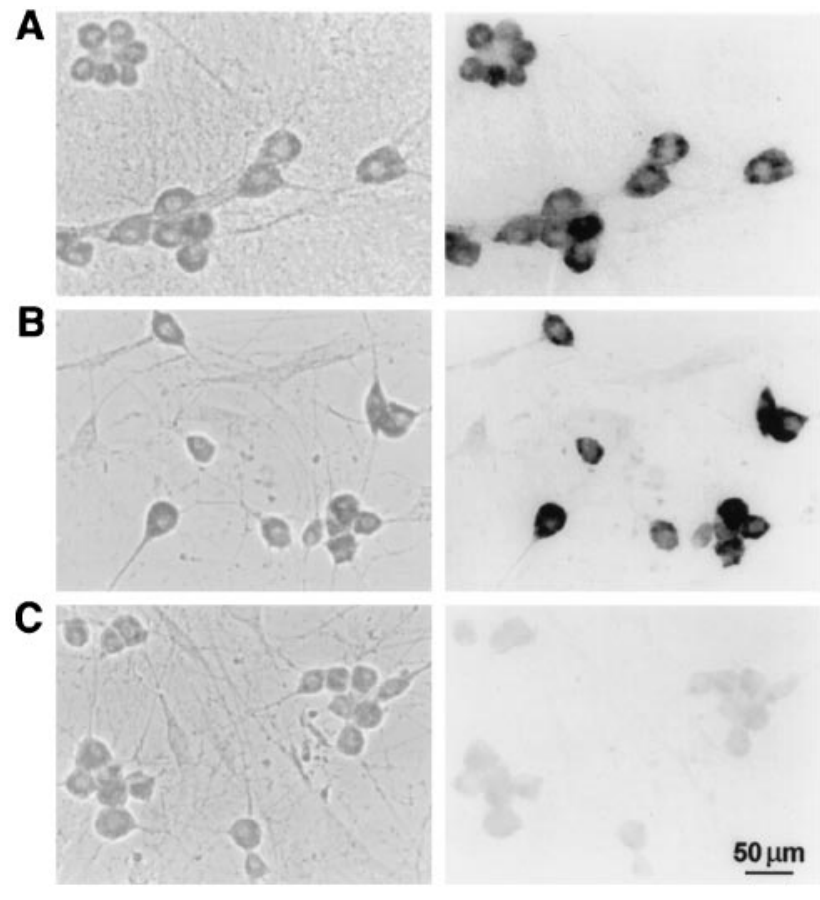

Figure 5. Most SCG and nodose neurons in culture express $5-\mathrm{HT}_{3} \mathrm{R}$ transcripts. In situ hybridization with DIG-labeled riboprobe for $5-\mathrm{HT}_{3} \mathrm{R}$ mRNA expression in P1 SCG and nodose neurons grown in culture for $7 \mathrm{~d}$ : $A$, SCG; $B$, nodose; $C$, control nodose neurons prehybridized with 400 -fold excess unlabeled antisense $5-\mathrm{HT}_{3} \mathrm{R}$ probe. Phase contrast (left) and DIC (right) photomicrographs were taken with a $40 \times$ objective on a Zeiss Axiovert 35 microscope. 5- $\mathrm{HT}_{3} \mathrm{R}$ mRNA is expressed by most $\mathrm{D} 7$ SCG and D7 nodose neurons.

rapid drop in 5- $\mathrm{HT}_{3} \mathrm{R}$ mRNA levels (Fig. $7 B$ ), indicating that increases in intracellular $\mathrm{Ca}^{2+}$ are unlikely to regulate $5-\mathrm{HT}_{3} \mathrm{R}$ mRNA levels in cultured nodose neurons.

The decrease $5-H T_{3} R m R N A$ levels requires protein synthesis. We added cycloheximide, a protein synthesis inhibitor, to cultures of P1 nodose neurons for the first $24 \mathrm{hr}$ after plating: this treatment mainly prevented the drop in $5-\mathrm{HT}_{3} \mathrm{R}$ mRNA levels, indicating that this decrease in nodose neurons is an active process that depends on de novo protein synthesis (Fig. 7B). In addition, treating neurons with cycloheximide for only the first $10 \mathrm{hr}$ partially prevented the drop in $5-\mathrm{HT}_{3} \mathrm{R}$ mRNA levels: the levels were $45 \%$ of initial levels after $24 \mathrm{hr}$ and $58 \%$ of initial levels after $48 \mathrm{hr}$ in culture (data not shown).

Interestingly, SCG neurons grown in culture show no such decrease in mRNA levels; this observation further demonstrates that $5-\mathrm{HT}_{3} \mathrm{R}$ gene expression is differentially regulated in these two types of neurons.

\section{Neurotrophins increase $5-H T_{3} R$ gene expression in cultured nodose neurons}

We observed that the decrease in $5-\mathrm{HT}_{3} \mathrm{R}$ mRNA levels in cultured nodose neurons is transient: after $2 \mathrm{~d}$ in culture, transcript levels begin to increase, and after $7 \mathrm{~d}$ in culture, 5- $\mathrm{HT}_{3} \mathrm{R}$ mRNA levels are above their initial levels (Fig. 7A). Because the neurotrophins NGF, BDNF, and NT-3 were present in these cultures, we asked whether these neurotrophins stimulated the delayed increase in $5-\mathrm{HT}_{3} \mathrm{R}$ gene expression. Because nodose neurons do not require exogenously supplied neurotrophins to grow in culture (Mandelzys and Cooper, 1992; De Koninck et al., 1993), we grew P1 nodose 
A

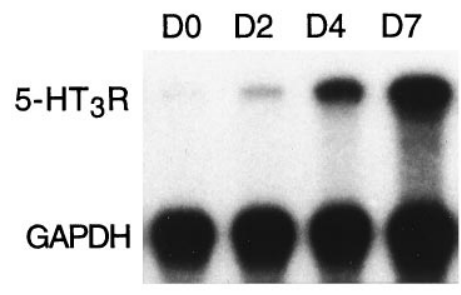

B

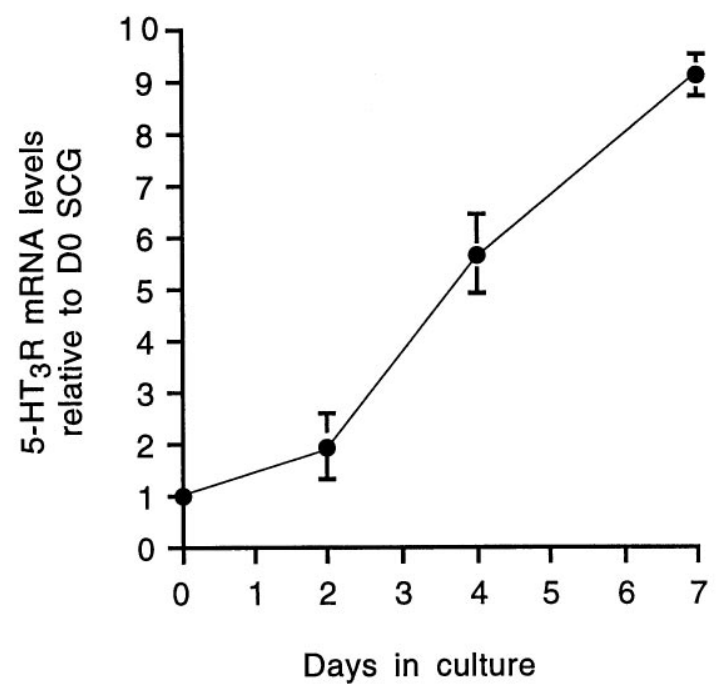

Figure 6. Developmental expression of $5-\mathrm{HT}_{3} \mathrm{R}$ transcripts by neonatal SCG neurons in culture. $A$, RNase protection assay performed as in Figure 1 on $1 \mu \mathrm{g}$ of total RNA extracted from freshly dissociated SCG day $0(D 0)$ neurons and SCG neurons grown in culture for 2,4 , and $7 \mathrm{~d}$. $B$, Quantification of 5- $\mathrm{HT}_{3} \mathrm{R}$ mRNA in cultured SCG neurons relative to D0. The values represent the mean of six to eight experiments, and the error bars represent the SEM.

neurons for $2 \mathrm{~d}$ without neurotrophins, allowing the drop in $5-\mathrm{HT}_{3} \mathrm{R}$ mRNA to occur, and then we divided the cultures into three groups. We used one group to measure $5-\mathrm{HT}_{3} \mathrm{R}$ mRNA levels at D2. We added $25 \mathrm{ng} / \mathrm{ml}$ of NGF, BDNF, and NT-3 to the second group and allowed the neurons to grow for an additional $5 \mathrm{~d}$. We grew the third group for an additional $5 \mathrm{~d}$ in the absence of neurotrophins. The number of neurons in all three groups did not differ by $>10 \%$. In the group receiving neurotrophins, the $5-\mathrm{HT}_{3} \mathrm{R}$ mRNA levels at D7 were 4.5 -fold greater than those at D2 (Fig. $7 C$ ), whereas in the group that did not receive neurotrophins, the levels were only 1.3 -fold greater than those at $\mathrm{D} 2$. These results suggest that neurotrophins stimulate $5-\mathrm{HT}_{3} \mathrm{R}$ expression in these neurons.

Correlation of 5-HT $R$ RRNA levels with 5-HT-evoked current densities

To determine whether changes in $5-\mathrm{HT}_{3} \mathrm{R}$ gene expression affect the appearance of functional $5-\mathrm{HT}_{3} \mathrm{Rs}$ on these neurons, we measured 5-HT-evoked currents on P1 nodose and SCG neurons developing in culture (Fig. $8 A$ ). We examined nodose neurons at two different times: early, after $1-3 \mathrm{~d}$ in culture, when $5-\mathrm{HT}_{3} \mathrm{R}$ mRNA levels in these neurons are low; and after 6-14 d in culture, when $5-\mathrm{HT}_{3} \mathrm{R}$ mRNA levels are four- to fivefold larger. Figure $8 B$ shows the mean 5-HT-evoked current densities for nodose neurons in culture for $1-3 \mathrm{~d}(n=36)$ and for $6-14 \mathrm{~d}(n=25)$ indicating that 5-HT-evoked current densities increase with time in culture. After $1-3 \mathrm{~d}$ in culture $83 \%$ of neurons (30 of 36) had 5-HT-evoked current densities below detectable levels $(<1 \mathrm{pA} / \mathrm{pF})$, whereas the mean 5-HT-evoked current density of the remaining $17 \%$ was 12.7 $\mathrm{pA} / \mathrm{pF} \pm 2.6 \mathrm{SEM}$. In comparison, after $6-14 \mathrm{~d}$ in culture only $20 \%$ of neurons (5 of 25 ) had current densities $<1 \mathrm{pA} / \mathrm{pF}$; the mean 5-HT-evoked current density of the remaining $80 \%$ was 36.5 $\mathrm{pA} / \mathrm{pF} \pm 6.9 \mathrm{SEM}$. These results demonstrate that changes in $5-\mathrm{HT}_{3} \mathrm{R}$ gene expression correlate directly with the appearance of functional $5-\mathrm{HT}_{3} \mathrm{Rs}$ on nodose neurons. We found a similar correlation for SCG neurons: most SCG neurons in culture for 1-3 d had small 5-HT-evoked current densities, and these 5-HT-evoked currents densities increased over the first week in culture.

\section{DISCUSSION}

In this study we have investigated factors and mechanisms that influence $5-\mathrm{HT}_{3} \mathrm{R}$ expression as sympathetic and nodose neurons differentiate during early postnatal life, a time when many autonomic reflexes become active. By comparing sympathetic and nodose neurons, we have identified cell type-specific mechanisms that regulate $5-\mathrm{HT}_{3} \mathrm{R}$ gene expression during neonatal development and as the neurons differentiate in culture. These mechanisms are likely to play a role in determining the appropriate spatial and temporal expression of $5-\mathrm{HT}_{3} \mathrm{Rs}$ in sensory and sympathetic neurons during early postnatal life.

Our results demonstrate that neonatal nodose and SCG neurons differ in $5-\mathrm{HT}_{3} \mathrm{R}$ mRNA expression. This differential expression may be attributable to the embryological origins of these two neuronal populations: SCG neurons originate from the neural crest, whereas nodose neurons are derived from the placodes (Le Douarin, 1984). Nodose neurons in vivo express high levels of $5-\mathrm{HT}_{3} \mathrm{R}$ mRNA: at P1, the levels are 14-fold greater than in SCG neurons and change little over the first 3 postnatal weeks. Presumably, these high levels ensure that nodose neurons express appropriate densities of functional 5- $\mathrm{HT}_{3} \mathrm{Rs}$ at birth. The 5- $\mathrm{HT}_{3} \mathrm{R}$ mRNA levels in sympathetic neurons increase 7.5-fold during the first 3 weeks of postnatal development. This increase may be related to increasing sympathetic target innervation during this neonatal period (Black, 1978). Less is known about the postnatal development of target innervation by rat nodose neurons. The lack of change in $5-\mathrm{HT}_{3} \mathrm{R}$ mRNA levels in nodose neurons during the first 3 postnatal weeks suggests either (1) that similar factors regulate $5-\mathrm{HT}_{3} \mathrm{R}$ expression in SCG and nodose neurons and that target innervation by vagal afferent neurons is essentially complete by birth or (2) that both types of neurons are increasing their target innervation during neonatal development, yet the factors that regulate $5-\mathrm{HT}_{3} \mathrm{R}$ gene expression in nodose and SCG neurons are different.

The increase in 5- $\mathrm{HT}_{3} \mathrm{R}$ mRNA levels in SCG neurons in vivo is much greater than the increase in neuronal $\mathrm{nAChR}$ subunit transcripts expressed by these neurons. We showed previously that the expression of the $\alpha_{3}$ and $\alpha_{7} \mathrm{nAChR}$ subunits increases four- and threefold, respectively, over a similar postnatal period, whereas as the expression of the other nAChR subunits, $\beta_{2}, \beta_{4}$, and $\alpha_{5}$, does not change significantly (Mandelzys et al., 1994). This indicates that in SCG neurons the regulation of $5-\mathrm{HT}_{3} \mathrm{R}$ gene expression differs from that of $\mathrm{nAChR}$ subunits. In addition, we show that the developmental increase in $5-\mathrm{HT}_{3} \mathrm{R}$ mRNA 
A
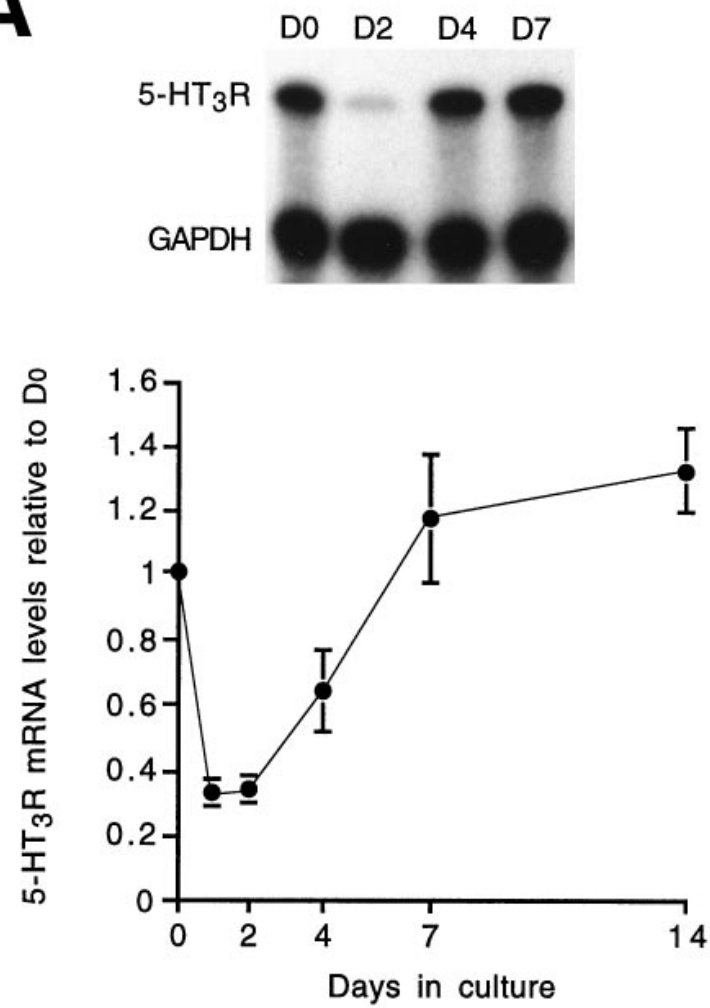

B

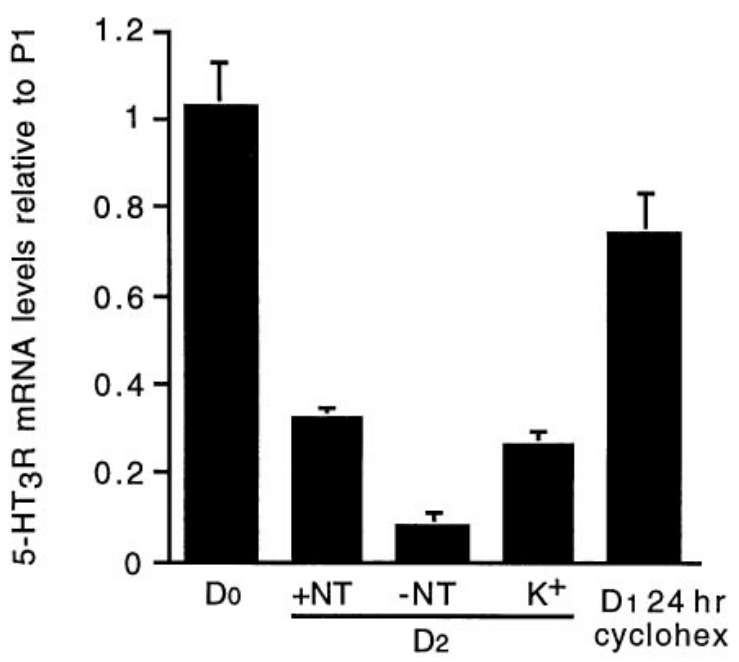

levels, like that for nAChR transcripts (Mandelzys et al., 1994), is not dependent on preganglionic innervation; this suggests that neither electrical activity nor factors derived from the preganglionic nerve terminals stimulate $5-\mathrm{HT}_{3} \mathrm{R}$ expression in these neurons.

Surprisingly, we observed a significantly greater increase in $5-\mathrm{HT}_{3} \mathrm{R}$ gene expression when neonatal SCG neurons develop in culture as compared with when they develop in vivo: after 1 week in culture $5-\mathrm{HT}_{3} \mathrm{R}$ mRNA levels increase ninefold versus a threefold increase over the same time period in vivo. The greater stimulation of $5-\mathrm{HT}_{3} \mathrm{R}$ expression in cultured $\mathrm{SCG}$ neurons presumably results from the removal of an inhibitory influence
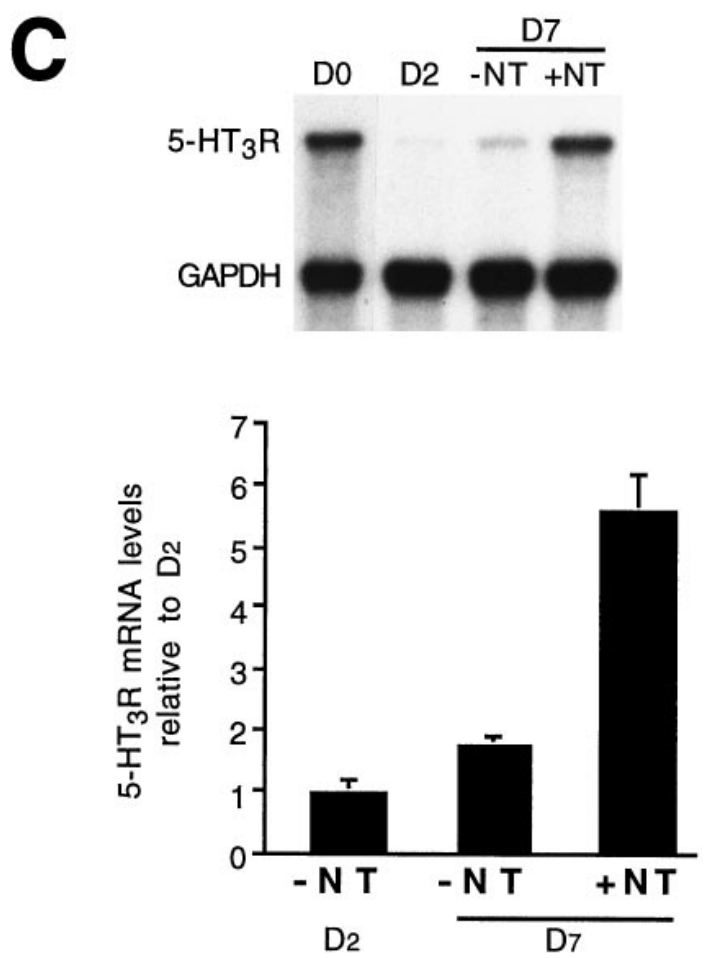

Figure 7. 5- $\mathrm{HT}_{3} \mathrm{R}$ mRNA levels decrease transiently in neonatal nodose neurons in culture. $A$, RNase protection assay and quantification performed as in Figure 1 on $1 \mu \mathrm{g}$ of total RNA extracted from freshly dissociated nodose (day 0 ) neurons and nodose neurons grown in culture in the presence of NGF, BDNF, and NT-3 for 2, 4, 7, and 14 d. $B$, Quantification of $5-\mathrm{HT}_{3} \mathrm{R}$ mRNA in cultured nodose neurons relative to P1: freshly dissociated $(D 0)$, with neurotrophins $(+N T)$ for $48 \mathrm{hr}$, without neurotrophins $(-N T)$ for $48 \mathrm{hr}$, with $40 \mathrm{mM} \mathrm{K}^{+}\left(\mathrm{K}^{+}\right)$for $48 \mathrm{hr}$, or with cycloheximide for $24 \mathrm{hr}$ (D1 24 hr cyclohex). C, Quantification of $5-\mathrm{HT}_{3} \mathrm{R}$ mRNA in cultured nodose neurons relative to D2 measured at D7. Nodose neurons were grown for $2 \mathrm{~d}$ without neurotrophins $(-N T)$ and then grown for 5 additional days with or without neurotrophins. 5 - $\mathrm{HT}_{3} \mathrm{R}$ mRNA levels in nodose neurons after $5 \mathrm{~d}$ in neurotrophins were significantly greater $(p<0.001)$ than neurons grown in the absence of neurotrophins. The values represent the mean of three separate cultures, and each RNA sample was assayed twice; the error bars represent the SEM. present in vivo, the addition of stimulatory factors to the cultures, or a combination of both. The greater increase in $5-\mathrm{HT}_{3} \mathrm{R}$ expression in cultured SCG neurons cannot be explained by changes in trkA or p75 receptor expression (M. R. and E. C., unpublished results).

When neonatal nodose neurons develop in culture in the presence of neurotrophins, 5- $\mathrm{HT}_{3} \mathrm{R}$ mRNA levels drop by $70 \%$ in 24 $\mathrm{hr}$, begin to increase after $48 \mathrm{hr}$, and are above initials levels after 1 week. This relatively rapid biphasic change in $5-\mathrm{HT}_{3} \mathrm{R}$ mRNA levels was unexpected because we did not observe a similar change in SCG neurons or with nodose neurons developing in vivo. We show that this increase in $5-\mathrm{HT}_{3} \mathrm{R}$ expression after $48 \mathrm{hr}$ 
A

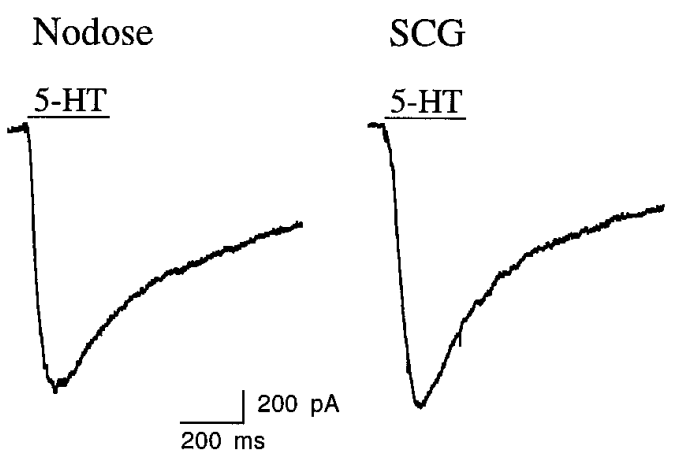

B

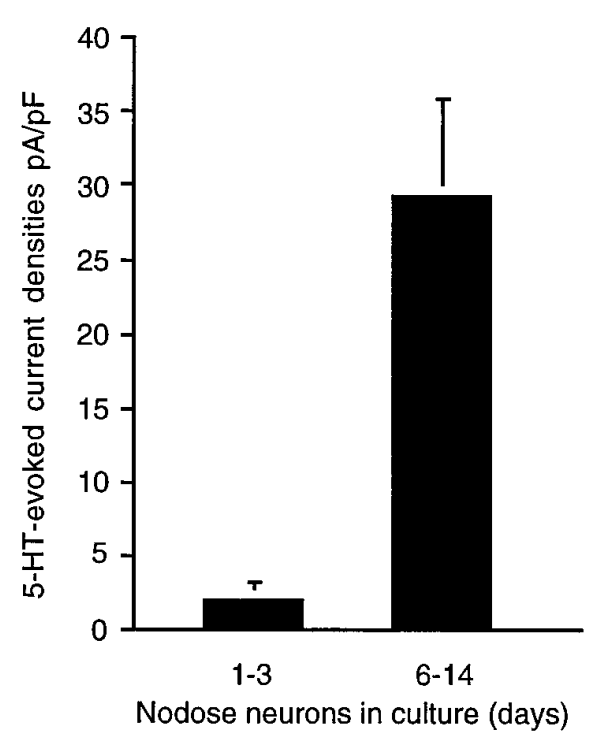

Figure 8. Nodose and SCG neurons express 5-HT-evoked currents. 5-HT-evoked currents were recorded from P1 nodose and SCG neurons grown in culture. $A$, Examples of 5-HT-evoked currents from D6 nodose and D7 SCG neurons. $B$, Mean 5-HT-evoked current densities $(\mathrm{pA} / \mathrm{pF})$ in nodose neurons grown for 1-3 d $(n=36)$ and $6-14 \mathrm{~d}(n=25)$; the error bars represent the SEM.

in culture is mediated by neurotrophins. The increase in $5-\mathrm{HT}_{3} \mathrm{R}$ expression cannot be explained by changes in neurotrophin receptor expression by nodose neurons over this time in culture (D. W. and E. C., unpublished results). Because neurotrophins are released from non-neuronal cells in degenerating peripheral nerve stumps after axotomy (Heumann et al., 1987; Raivich et al., 1991), as well as from target tissues, this mechanism could ensure that, after a brief delay $(24 \mathrm{hr})$, regenerating nodose axons will continue to express $5-\mathrm{HT}_{3} \mathrm{R}$. Conceivably, neurotrophins also play a role in regulating $5-\mathrm{HT}_{3} \mathrm{R}$ expression in SCG neurons.

The initial rapid drop in 5- $\mathrm{HT}_{3} \mathrm{R}$ mRNA levels is likely attributable to the effects of axotomy, because the axons of these neurons are cut when they are placed in culture. We show that cutting the peripheral branch of nodose axons in neonatal animals results in a rapid $60 \%$ decrease in $5-\mathrm{HT}_{3} \mathrm{R}$ mRNA levels in $24 \mathrm{hr}$. The decrease we observed in cultured neurons is greater than that in axotomized neurons in vivo, presumably because in cultured nodose neurons both the central and peripheral axons were cut. This indicates that the high $5-\mathrm{HT}_{3} \mathrm{R}$ transcript levels in developing nodose neurons are actively maintained by mechanisms that depend on intact innervation, possibly involving target-derived factors, similar to what has been shown for nAChRs in chick ciliary neurons (Jacob and Berg, 1987; Levey et al., 1995; Levey and Jacob, 1996). Similar decreases in mRNA and protein levels have been reported for a number of neuropeptides and their receptors after axotomy of sensory neurons, and the decrease of many of these proteins can be prevented by target-derived factors (Herdegen and Zimmerman, 1994; Hökfelt et al., 1994a,b). However, we show that the rapid drop in $5-\mathrm{HT}_{3} \mathrm{R}$ mRNA levels in cultured nodose neurons is not prevented by neurotrophins, suggesting that cutting the axons may initiate events that actively decrease $5-\mathrm{HT}_{3} \mathrm{R}$ mRNA levels in nodose neurons.

Our results on culturing nodose neurons in elevated $\mathrm{K}^{+}$indicate that chronic depolarization and the resulting increase in intracellular $\mathrm{Ca}^{2+}$ do not prevent the drop in $5-\mathrm{HT}_{3} \mathrm{R}$ mRNA levels. These experiments suggest that the rapid drop in $5-\mathrm{HT}_{3} \mathrm{R}$ mRNA levels in cultured nodose neurons, and presumably after axotomy in vivo, is not a result of $\mathrm{Ca}^{2+}$-dependent second messenger pathways. When we treat nodose cultures with cycloheximide, a protein synthesis inhibitor, the initial decrease in $5-\mathrm{HT}_{3} \mathrm{R}$ mRNA levels in large part is prevented, suggesting that this decrease is an active process that requires de novo protein synthesis.

Our results indicate that the biphasic change in 5- $\mathrm{HT}_{3} \mathrm{R}$ mRNA levels in cultured nodose neurons represents the net effect of two separate processes that regulate gene expression: one triggered by axotomy that decreases $5-\mathrm{HT}_{3} \mathrm{R}$ mRNA levels and the other mediated by neurotrophins that increase these levels. Because the drop occurs during the first $24 \mathrm{hr}$, even in the presence of neurotrophins, the events initiated by axotomy in nodose neurons must outweigh the stimulatory effects of neurotrophins but are short-lived. We did not observe any decrease in $5-\mathrm{HT}_{3} \mathrm{R}$ mRNA levels in cultured SCG neurons. One possible explanation is that the stimulatory effects of neurotrophins on sympathetic neurons override the effects of axotomy. A second possibility is that sympathetic neurons differ from sensory neurons in their response to axotomy.

To address whether changes in $5-\mathrm{HT}_{3} \mathrm{R}$ gene expression affect the appearance of functional $5-\mathrm{HT}_{3} \mathrm{Rs}$, we measured 5-HTevoked currents on nodose and SCG neurons in culture. Our electrophysiological results indicate that changes in $5-\mathrm{HT}_{3} \mathrm{R}$ mRNA levels correlate well with the appearance of functional $5-\mathrm{HT}_{3} \mathrm{R}$ on these neurons. For nodose neurons, after $1-3 \mathrm{~d}$ in culture when $5-\mathrm{HT}_{3} \mathrm{R}$ mRNA levels are low, we found that few neurons had detectable 5-HT-evoked currents, whereas 6-14 d later $>80 \%$ had detectable 5 -HT-evoked currents. Similar results were observed for SCG neurons in culture. Our results demonstrate that changes in $5-\mathrm{HT}_{3} \mathrm{R}$ gene expression directly reflect changes in the appearance of functional receptors.

\section{REFERENCES}

Andresen M, Kunze D (1994) Nucleus tractus solitarius-gateway to neural circulatory control. Annu Rev Physiol 56:93-116.

Apud JA (1993) The 5- $\mathrm{HT}_{3}$ receptor in mammalian brain: a new target for the development of psychotropic drugs? Neuropsychopharmacology 8:117-130.

Barthel L, Raymond P (1993) Subcellular localization of $\alpha$-tubulin and opsin mRNA in the goldfish retina using digoxigenin-labeled cRNA probes detected by alkaline phosphatase and HRP histochemistry. J Neurosci Methods 50:145-152.

Black IB (1978) Regulation of autonomic development. Annu Rev Neurosci 1:183-214.

Chomczynski P, Sacchi N (1987) Single-step method of RNA isolation 
by acid guanidium thiocyanate-phenol-chloroform extraction. Anal Biochem 162:156-159.

De Koninck P, Cooper E (1995) Differential regulation of neuronal nicotinic $\mathrm{ACh}$ receptor subunit genes in cultured neonatal rat sympathetic neurons: specific induction of alpha 7 by membrane depolarization through a $\mathrm{Ca}^{2+} /$ calmodulin-dependent kinase pathway. J Neurosci 15:7966-7978.

De Koninck P, Carbonetto S, Cooper E (1993) NGF induces neonatal rat sensory neurons to extend dendrites in culture after removal of satellite cells. J Neurosci 13:577-585.

Derkach V, Surprenant A, North RA (1989) 5- $\mathrm{HT}_{3}$ receptors are membrane ion channels. Nature 339:706-709.

Donoghue S, Garcia M, Jordan D, Spyer KM (1982) Identification and brain-stem projections of aortic baroreceptor afferent neurones in nodose ganglia of cats and rabbits. J Physiol (Lond) 322:337-352.

Douglas W (1975) Histamines and antihistamines; 5-hydroxytryptamine and antagonists. In: The pharmacological basis of therapeutics, 5th Ed (Goodman L, Gilman A, eds), pp 590-624. New York: Macmillan.

Downie DL, Hope AG, Lambert JJ, Peters JA, Blackburn TP, Jones BJ (1994) Pharmacological characterization of the apparent splice variants of the murine $5-\mathrm{HT}_{3} \mathrm{R}-\mathrm{A}$ subunit expressed in Xenopus laevis oocytes. Neuropharmacology 33:473-482.

Fozard JR (1984) Neuronal 5-HT receptors in the periphery. Neuropharmacology 23:1473-1486.

Greenshaw AJ (1993) Behavioral pharmacology of 5- $\mathrm{HT}_{3}$ receptor antagonists: a critical update on therapeutic potential. Trends Pharmacol Sci 14:265-270.

Hamil OP, Marty A, Neher E, Sakmann B, Sigworth F (1981) Improved patch-clamp techniques for high resolution current recording from cells and cell-free membrane patches. Pflügers Arch 391:85-100.

Hawrot E, Patterson P (1979) Long-term culture of dissociated sympathetic neurons. Methods Enzymol 58:574-584.

Herdegen T, Zimmerman M (1994) Expression of c-Jun and JunD transcription factors represent specific changes in neuronal gene expression following axotomy. Prog Brain Res 103:153-171.

Heumann R, Lindholm D, Bandtlow C, Meyer M, Radeke MJ, Misko TP, Shooter E, Thoenen H (1987) Differential regulation of mRNA encoding nerve growth factor and receptor in rat sciatic nerve during development, degeneration, and regeneration: role of macrophages. Proc Natl Acad Sci USA 84:8735-8739.

Hökfelt T, Ceccatelli S, Gustafsson L, Hulting A-L, Verge V, Villar M, Xu X-J, Xu Z-Q, Zhang X, Wiesenfeld-Hallin Z, Zhang X (1994a) Plasticity of NO synthase expression in the nervous and endocrine system. Neuropharmacology 33:1221-1227.

Hökfelt T, Zhang X, Wiesenfeld-Hallin Z (1994b) Messenger plasticity in primary sensory neurons following axotomy and its functional implications. Trends Neurosci 17:22-30.

Jackson M, Yakel J (1995) The 5- $\mathrm{HT}_{3}$ receptor channel. Annu Rev Physiol 57:447-468.

Jacob M, Berg D (1987) Effects of preganglionic denervation and postganglionic axotomy on acetylcholine receptors in the chick ciliary ganglion. J Cell Biol 105:1847-1854.

Johnson D, Heinemann S (1995) Embryonic expression of the 5- $\mathrm{HT}_{3}$ receptor subunit, $5-\mathrm{HT}_{3} \mathrm{R}-\mathrm{A}$, in the rat: an in situ hybridization study. Mol Cell Neurosci 6:122-133.

Krieg PA, Melton DA (1987) In vitro RNA synthesis with SP6 RNA polymerase. Methods Enzymol 155:397-415.

Le Douarin NM (1984) Ontogeny of the peripheral nervous system from the neural crest and the placodes. A developmental model studied on the basis of the quail-chick chimaera system. Harvey Lect 80:137-186.

Levey MS, Jacob M (1996) Changes in the regulatory effects of cell-cell interactions on neuronal AChR subunit transcript levels after synapse formation. J Neurosci 16:6878-6885.
Levey MS, Brumwell CL, Dryer SE, Jacob M (1995) Innervation and target tissue interactions differentially regulate acetylcholine receptor subunit mRNA levels in developing neurons in situ. Neuron 14:153-162.

Litman P, Barg J, Rindzoonski L, Ginzburg I (1993) Subcellular localization of tau mRNA in differentiating neuronal cell cultures: implications for neuronal polarity. Neuron 10:627-638.

Mandelzys A, Cooper E (1992) Effects of ganglionic satellite cells and NGF on the expression of nicotinic acetylcholine currents by rat sensory neurons. J Neurophysiol 67:1213-1221.

Mandelzys A, Pié B, Deneris E, Cooper E (1994) The developmental increase in $\mathrm{ACh}$ current densities on rat sympathetic neurons correlates with changes in nicotinic $\mathrm{ACh}$ receptor $\alpha$-subunit gene expression and occurs independent of innervation. J Neurosci 14:2357-2364.

Mandelzys A, De Koninck P, Cooper E (1995) Agonist and toxin sensitivities of ACh-evoked currents on neurons expressing multiple nicotinic ACh receptor subunits. J Neurophysiol 74:1212-1221.

Maricq A, Peterson A, Brake A, Myers R, Julius D (1991) Primary structure and functional expression of the $5 \mathrm{HT}_{3}$ receptor, a serotoningated ion channel. Science 254:432-437.

Martin D, Schmidt R, DiStefano P, Lowry O, Carter J, Johnson EM (1988) Inhibitors of protein synthesis and RNA synthesis prevent neuronal death caused by nerve growth factor deprivation. J Cell Biol 106:829-844.

McFarlane S, Cooper E (1992) Postnatal development of voltage-gated K currents on rat sympathetic neurons. J Neurophysiol 67:1291-1300.

Mei N (1970) Disposition anatomique et propriétés électrophysiologiques des neurones sensitifs vagaux chez le chat. Exp Brain Res 11:465-479.

Miquel M-C, Emerit M, Gingrich J, Nosjean A, Hamon M, El Mestikawy $\mathrm{S}$ (1995) Developmental changes in the differential expression of two serotonin $5-\mathrm{HT}_{3}$ receptor splice variants in the rat. $\mathrm{J}$ Neurochem 65:475-483.

Miyake A, Mochizuki S, Takemoto Y, Akuzawa S (1995) Molecular cloning of human 5-hydroxytryptamine ${ }_{3}$ receptor: heterogeneity in distribution and function among species. Mol Pharmacol 48:407-416.

Portalier P, Vigier D (1979) Localization of aortic cells in the nodose ganglion by HRP retrograde transport in the cat. Neurosci Lett 11:7-11.

Raivich G, Hellweg R, Kreutzberg GW (1991) NGF receptor-mediated reduction in axonal NGF uptake and retrograde transport following sciatic nerve injury and during regeneration. Neuron 7:151-164.

Rosenberg M, Séguéla P, Cooper E (1994) Developmental expression of $5-\mathrm{HT}_{3}$ receptor mRNA in rat sympathetic and sensory neurons. Soc Neurosci Abstr 20:474.2.

Sanders-Bush E, Mayer S (1996) 5-Hydroxytryptamine (serotonin) receptor agonists and antagonists. In: The pharmacological basis of therapeutics, 9th Ed (Hardmann J, Limbird L, Molinoff P, Ruddon R, Goodman A, Gilman A, eds), pp 249-257. New York: McGraw-Hill.

Smolen A, Raisman G (1980) Synapse formation in the rat superior cervical ganglion during normal development and after neonatal deafferentation. Brain Res 181:315-323.

Tecott L, Shtrom S, Julius D (1995) Expression of a serotonin-gated ion channel in embryonic neural and nonneural tissues. Mol Cell Neurosci $6: 43-55$.

Voyvodic J (1987) Development and regulation of dendrites in the rat superior cervical ganglion. J Neurosci 7:904-912.

Wallis DI, North RA (1978) The action of 5-hydroxytryptamine on single neurones of the rabbit superior cervical ganglion. Neuropharmacology 17:1023-1028.

Yakel J, Jackson M (1988) $5-\mathrm{HT}_{3}$ receptors mediate rapid responses in cultured hippocampus and a clonal cell line. Neuron 1:615-621.

Yang J, Mathie A, Hille B (1992) 5-HT3 receptor channels in dissociated rat superior cervical ganglion neurons. J Physiol (Lond) 448:237-256. 